\title{
パラレルワイヤ駆動機構を用いた立位バランス能力の測定
}

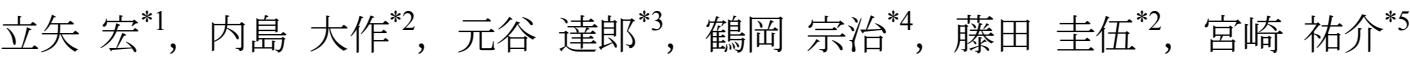

\section{Measurement of standing balance ability by a wire driven parallel mechanism}

\author{
Hiroshi TACHIYA ${ }^{* 1}$, Daisaku UCHIJIMA ${ }^{* 2}$, Tatsuro MOTOYA ${ }^{* 3}$, Muneharu TSURUOKA $^{* 4}$, \\ Keigo FUJITA $^{* 2}$ and Yusuke MIYAZAKI ${ }^{* 5}$ \\ ${ }^{{ }_{1} 1}$ Institute of Science and Engineering, Faculty of Mechanical Engineering, Kanazawa University \\ Kakuma-machi, Kanazawa-shi, Ishikawa 920-1192, Japan \\ ${ }^{* 2, * 3, * 4}$ Graduate School of Natural Science and Technology, Kanazawa University \\ Kakuma-machi, Kanazawa-shi, Ishikawa 920-1192, Japan \\ ${ }^{* 5}$ Graduate School of Information Science and Technology, Tokyo Institute of Technology \\ 2-12-1, Ookayama, Meguro-ku, Tokyo 152-8552, Japan
}

Received 7 March 2014

\begin{abstract}
Falls are a major reason for elderly people to require nursing care. Prevention of falls requires evaluation of standing balance ability of human. Thus various measurements were performed and the relation between the results and occurrence of falls was considered. Although these measurements were mainly done under stable upright posture, the measurements of balance ability should be done under near falling. However, from a viewpoint of safety of subjects, the occurrences of falls which may inflict damage on them must be avoided during the measurements. This study, thus, develops a device that can measure standing balance of subjects until falls. The device consists of a three degree of freedom (3DOF) wire driven parallel mechanism, the output link of which is attached to a subject. The device can control 3DOF rotational motion of the output link by wires. Each wire has strain-gages to detect the forces applied to the output link and judge the falling moment. Furthermore, a force-plate is set on the base to measure the center of pressure (COP) of a subject. The device can guide subjects in specified direction at the measurement and support them safely at falling. We measured the COP at the fall moment and the body sways on tilting posture by the proposed device. As a result, it is found that the differences between subjects become clearer as their postures tilt closer to fall moment.
\end{abstract}

Key words : Fall, Wire driven parallel mechanism, Medical engineering, Medical equipment, Mechanism

\section{1. 緒言}

高齢者の転倒による骨折は高い頻度で生じており（安村，1999)，死亡や要介護にいたる主要因となっている (厚生労働省，2010). そこで，ヒトの転倒のしやすさを把握するために，立位バランス能力に関する測定や検討 が多数行われている. 特に，接地面上の足圧中心 (center of pressure: COP) の位置の変化による重心動摇に関し て, 年齢, 性別などによる差異, 転倒の有無との関連 (堀川他, 1999; 今本他, 2005; 木村, 2000; Kouzaki and Masani, 2012; 小栢他，2010), さらに，モデルを用いた解析が検討されている (Bottaro, et al., 2005; Freitas, et al., 2009).

立位バランス能力の測定は，被験者の安全を確保するため通常は安定した直立姿勢で行われる。しかし，同状

No.14-00133 [DOI: 10.1299/transjsme.14-00133], J-STAGE Advance Publication date : 26 December, 2014

${ }^{* 1}$ 正員, 金沢大学理工研究域機械工学系(广920-1192 石川県金沢市角間町)

*2 金沢大学大学院自然科学研究科

*3 正員, 金沢大学大学院自然科学研究科

${ }^{* 4}$ 学生員, 金沢大学大学院自然科学研究科

*5 正員, 東京工業大学大学院情報理工学研究科情報環境学専攻（機械系）(广152-8552 東京都目黒区大岡山 2-12-1)

E-mail of corresponding author: tachiya@se.kanazawa-u.ac.jp 
態は平衡を保つための筋力や感覚などを必ずしも活発に使用している状態ではなく，バランスを失う直前の状態 との差は大きい，立位バランスに関する能力をより的確に把握するには，バランスを保てなくなる瞬間の COP の位置などを明らかにし，その個人差や年齢による変化を検討することが望ましいと考えられる．また，実際に 転倒のし易さは, 姿勢保持が困難な状況での立位バランス能力が, より強く関連することが指摘されている (木 村, 2000). しかし, ヒトのバランス能力の測定においては, 被験者を転倒させ負傷させることは絶対に避けなけ ればならないため, バランスを失ってしまう姿勢近傍での測定は立位状態に関してほとんど行われていない。

著者らは先に，座位状態で転倒にいたるまでのバランス能力が測定可能な装置を，パラレルワイヤ駆動機構を 用いて開発し (立矢他，2010), 被験者の安全を確保しながら転倒が生じや寸い座位姿勢などが測定可能であるこ とを確認した. パラレルワイヤ駆動機構はワイヤで出力節を駆動するため可動部を小型・軽量化でき, かつ, 柔 軟性を有することから人体に装着しや寸い，また，ワイヤ張力などの測定により被験者の転倒を速やかに検知で きる，そこで，本論文でも同機構を用い，座位状態に比べ，より転倒が生じや寸い立位状態で，転倒にいたるま でのバランス能力を安全に測定可能な装置を製作し，これまで困難であった被験者がバランスを失う瞬間の COP の位置や，姿勢を傾斜させた状態での重心動摇を測定して，安定した直立状態での結果などと比較し，その有用 性を検討する.

なお，本論文で実施する測定に関しては金沢大学医学倫理委員会から 2011 年 2 月 16 日に承認を得ている.

\section{2. 立位バランス能力測定装置}

立位バランス能力測定装置の概要を図 1 に示寸．同装置の主要部には，図 2 に示寸 3 自由度パワレルワイヤ駆 動機構 (立矢他，2010) を用いる. 同機構は 3 自由度の球対偶を介して支柱で連結する赤枠の出力節を 4 本のワ イヤの伸縮で任意軸周りに回転できる. 出力節は人体を支持するサポート部として用いる．ワイヤは図 2 のとお り出力節上の $\mathrm{J}_{\mathrm{O}, i}(i=1 \sim 4)$ に連結し， $\mathrm{J}_{\mathrm{B}, i}(i=1 \sim 4)$ に配置したモータで長さを調節する.

測定時の姿勢などを表すため, ベースには球対偶の中心を原点とする静止座標系 O-XYZを, サポート部とする 出力節には支柱の中心を原点 $\mathrm{P}$ とする動座標系 P- $x_{p} y_{p} z_{p}$ を図 2 に示すとおり設ける，サポート部の姿勢は， $X, Y$ および $Z$ 軸周りの順に回転する角変位 $\alpha, \beta$ および $\gamma$ で表す. なお, 初期姿勢において $X, Y, Z$ 軸と動座標系の $x_{p}, y_{p}, z_{p}$ 軸の方向はそれぞれ同一とし， $\alpha, \beta$ および $\gamma$ を零とする.

初期姿勢での機構の寸法を図 2 中の記号を用い表 1 に示寸. $\mathrm{J}_{\mathrm{B}, \mathrm{i}}(i=1 \sim 4)$ には, AC サーボモータ (多摩川精機 TS4609，定格トルク $26.4 \mathrm{Nm}$ ）を配置する. 出力節の傾斜角範囲は， $\alpha, \beta, \gamma= \pm 20 \operatorname{deg}$ とする. これらは成人男

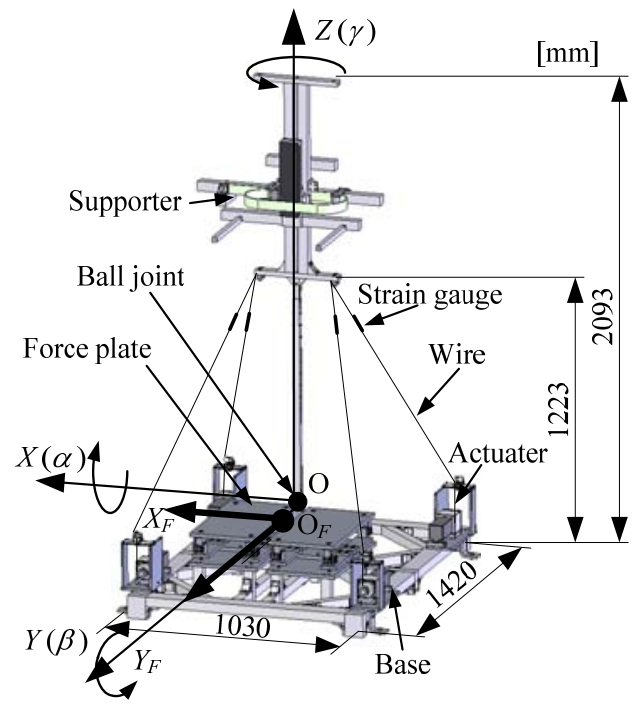

Fig. 1 Experimental device measuring standing balance

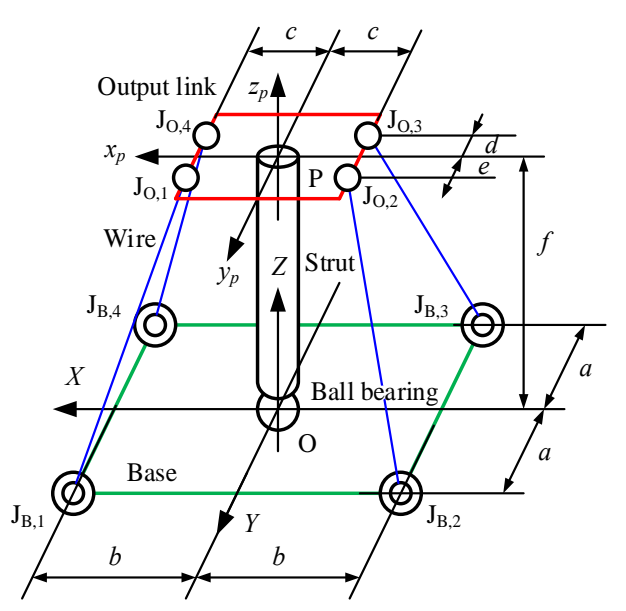

Fig. 2 Spatial 3dof wire driven parallel mechanism

Table 1 Size of the experimental device [mm]

\begin{tabular}{c|c|c|c|c|c}
\hline$a$ & $b$ & $c$ & $d$ & $e$ & $f$ \\
\hline \hline 500 & 600 & 200 & 0 & 0 & 900 \\
\hline
\end{tabular}


性（身長 $1800 \mathrm{~mm}$ 以下，体重 $85.0 \mathrm{~kg}$ 以下）の装着を前提に決定した.

パワレルワイヤ駆動機構の出力節には身体のサポート部を取り付け，被験者の胸部周りに装着する．サポート 部には図 1 のようなベルトまたは後述のハーネスを用いる．測定時に被験者がバランスを失った場合はサポート 部で被験者の姿勢を保持し安全を確保する.

各ワイヤには, ひずみゲージを貼り付けた $1 \mathrm{kN}$ までの張力が測定可能な金属製のプレートを連結する. 被験者 の足元には製作したフォースプレートを設置しCOP を測定する. フォースプレートは，一辺の長さが $350 \mathrm{~mm} の$ 正方形状であり，プレート上の 8 箇所の荷重值を測定し，得られた結果から，あらかじめ校正実験より導いた実 験式によって, $X Y$ 平面に作用する被験者の重量を $1.0 \mathrm{~N}, \operatorname{COP}$ の位置を $1.0 \mathrm{~mm}$ の分解能で測定する.

フォースプレート上には, 図 1 に示すように静止座標系 $\mathrm{O}_{F}-X_{F} Y_{F}$ を設定し, 被験者の COP の位置を表す. なお, 同座標系の原点 $\mathrm{O}_{F}$ はフォースプレートの中心で， $Y_{F}$ 軸は $Y$ 軸と一致しており，点 $\mathrm{O}$ と点 $\mathrm{O}_{F}$ 間の距離は $230 \mathrm{~mm}$ である.

なお，被験者の転倒防止方法としては，吊り下げ式の免荷装置が一般的であり，歩行訓練などに用いられてい る (毛利他, 2009). 同装置と比較して, パラレルワイヤ駆動機構は出力節の姿勢制御のため, 全てのワイヤに常 に張力を作用させておく必要があるため扱いが容易でなく, また, 被験者の動きに応じて速やかに身体のサポー 卜部である出力節を移動させることは困難であることから，歩行訓練などでの転倒防止装置としては適していな い.しかし，本論文で実施する立位バランス能力の測定では，被験者の姿勢を詳細に指示し，再現性の高い実験 を行うことを目的としており，吊り下げ式免荷装置を身体の保持に用いた場合は，姿勢の指示や，また，転倒の 発生を即時に検知寸る装置の追加が必要であることから, 結果的に装置全体が大型化する可能性がある. これに 対し，パラレルワイヤ駆動機構を用いれば，姿勢の指示と，転倒を検知し姿勢を保持することが，以上で述べた とおり行えるため, 装置全体の小型化が期待できる.

\section{3. 足圧中心（COP）の可動域}

\section{$3 \cdot 1$ COP 可動域}

本論文では, 被験者が静止立位状態で身体を傾斜させた場合にバランスを保てなくなる限界を転倒限界と呼び, 転倒限界にいたるまでの COP が移動可能な範囲を COP 可動域とする. 緒言で述べたように, 提案する装置は身 体を傾斜させた不安定な状態での重心動摇の測定が目的の一つである. そのために, 傾斜可能な姿勢の範囲をお およそ知ることは重要であり, COP 可動域はそのために有用である. また, その測定值から, 被験者のバランス 能力の評価も可能であると考えられる，従来は転倒による負傷などを防ぐため, 被験者の姿勢を転倒するまで変 化させることは困難であったが，本装置を用いればそれが可能となる，以下では，被験者の転倒限界での COP の測定值から COP 可動域を求め, その結果を検討する.

\section{$3 \cdot 2$ 装置の装着方法}

測定装置を装着した被験者の正面および側面からの様子を図3(a)および(b)に示す，サポート部はベルト式であ る. 測定時には図 4 に示寸ように被験者の初期姿勢での立ち位置を指定する．まず，図 4(a)のとおり，被験者の 背中および臀部を結ぶ青破線が $Z$ 軸とほぼ平行になるように立位姿勢をとり, 被験者の肩峰点, 大腿骨の大転子, くるぶしの $20 \mathrm{~mm}$ 前方の位置を接続した赤破線が $Z$ 軸と平行になるようにする. $Z$ 軸と被験者背面までの距離は 約 $80 \mathrm{~mm}$ とする. 次に, 足部は図 4(b)に示すように, 青破線で示す足指の内側の接線をおおよそ $Y$ 軸に平行とし, 図 4(b)に $X Y$ 平面上への投影で示寸ように, 背中から肩峰点までの距離 $L_{s}[\mathrm{~mm}]$ と, くるぶしから足先先端までの 距離 $L_{u}[\mathrm{~mm}]$ を測定する.これらの值より，くるぶしが前述した位置となるように原点 O から被験者の足先の距 離 $L_{t}$ の值を指示する.

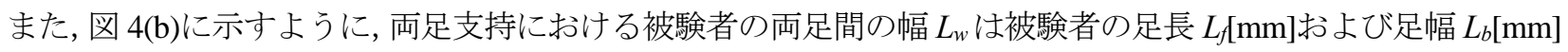
を考慮し，足部接地面を囲う矩形が，いずれの被験者においても正方形となるように次式で算出する.

$$
L_{w}=L_{f}-2 L_{b}
$$


なお，右足と左足の位置は $Y$ 軸に対称とする. さらに，図 4(c)に示すように，片足支持における足の接地位置 は，第 2 指先端と踵後端を結ぶ直線が $Y$ 軸と重なるように設定する.

\section{$3 \cdot 3$ 測定方法}

測定は両足および片足支持状態を対象に以下の手順で行った.

(1) 装置を初期姿勢として被験者の胸部をサポート部のベルトで囲む. 被験者は $3 \cdot 2$ 節で述べた直立姿勢とする.

（2）サポート部の傾斜方向を設定後，装置を動作させて COP の測定を開始する．被験者は，身体がサポート部 にふれる程度に装置の動作に追従し，身体を傾斜させていく．ただし，姿勢の変化は足関節の回転で行い，足関 節より上部は直立姿勢を保つようにする。

（3）被験者は，立位状態を保つことが不可能となりバランスを失った瞬間にサポート部に身体を託す．装置は， 被験者がバランスを保てなくなりサポート部に寄りかかったときのワイヤ張力の増加を検知すると同時にサポー 卜部の動作を停止し，初期姿勢に復帰する.

被験者の両足支持の様子は図 3 に示寸とおりである，また，片足支持では図 5 に示すように，支持脚の膝を伸 ばし, 遊脚の脛側中足点を支持脚の内果に接触させる. サポート部の動作は, 被験者が容易に追従できる $1.0 \mathrm{deg} / \mathrm{s}$ の等速回転運動とした. 測定時には COP およびワイヤ張力を $20 \mathrm{~Hz}$ のサンプリングレートで測定した. 両足支持 における傾斜方向は図6(a)に示す(1)〜10)の順に計10方向, 片足支持は図6(b)に示す(1)〜 (7)の順に計 7方向とした.

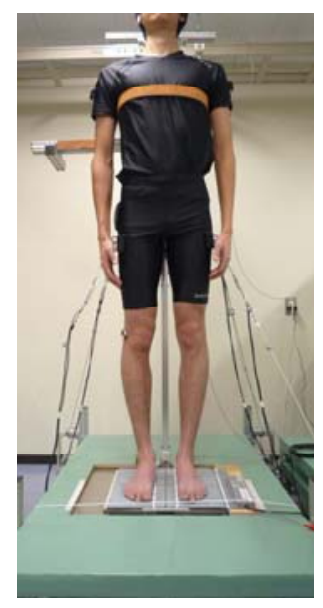

(a) Front

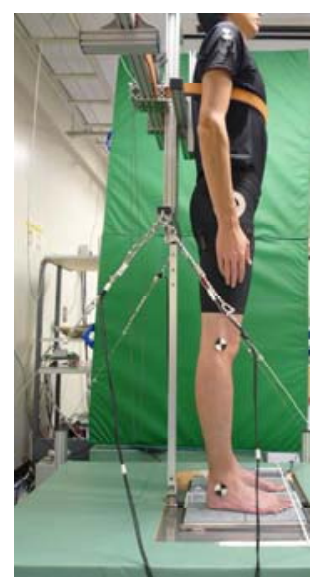

(b) Side

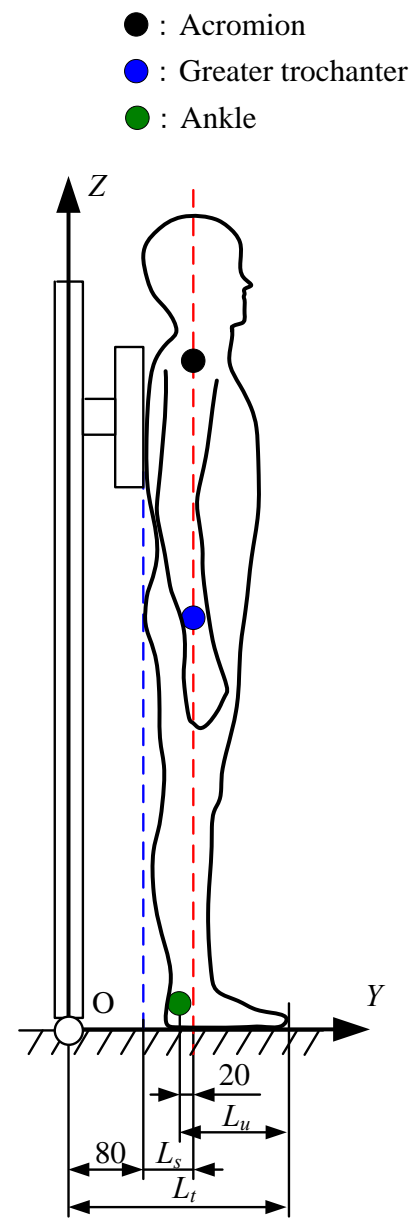

(a) Side view

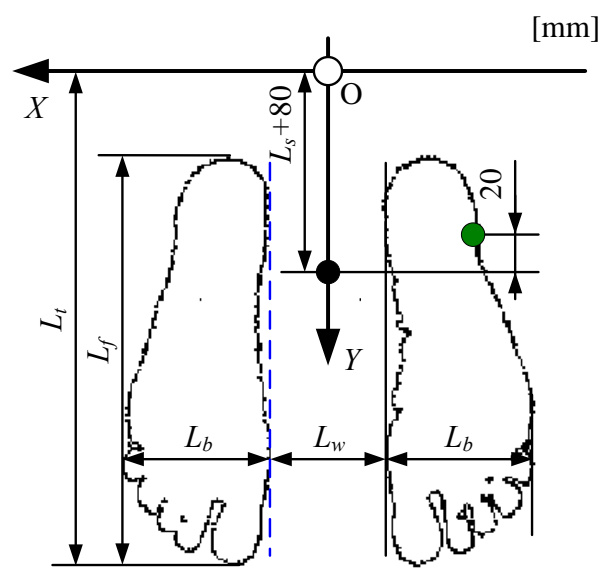

(b) Footprints of standing on both feet

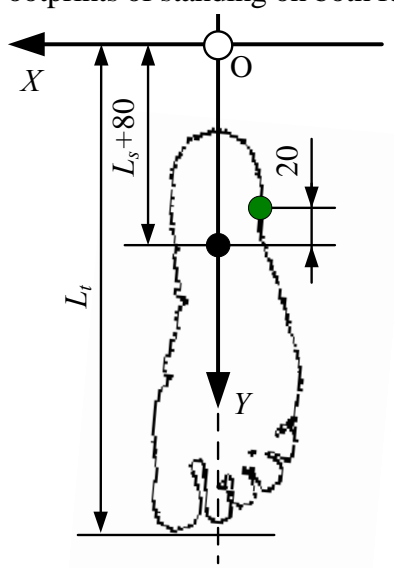

(c) Footprint of standing on one foot

Fig. 3 Experimental situation

Fig. 4 Initial posture and position 


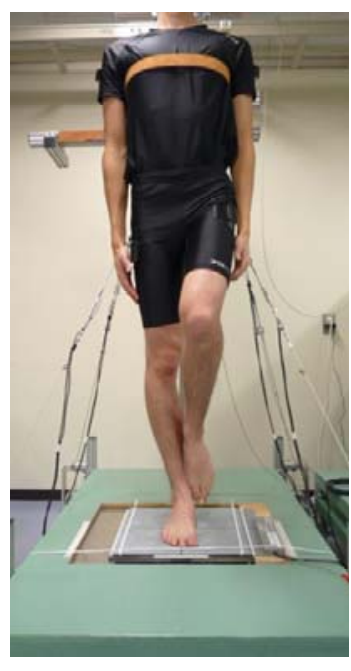

Fig. 5 Standing posture on one foot

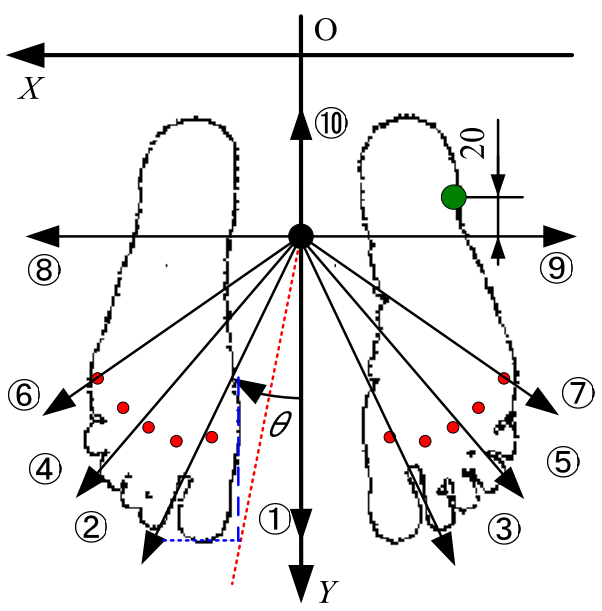

: Projected point of ankle

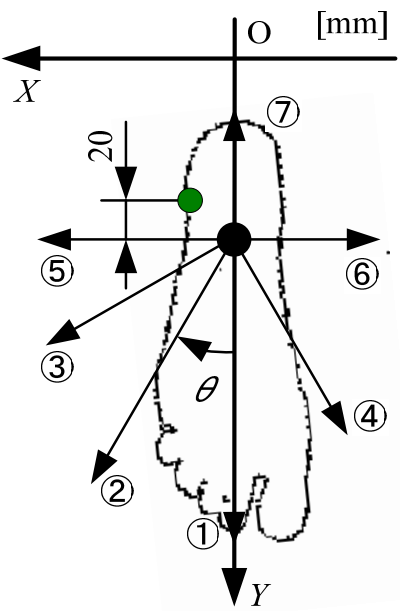

- : MP joint

(b) Footprint of standing on one foot

(a) Footprints of standing on both feet

Fig. 6 Tilting direction

なお，両足支持における(2)～(7)の傾斜方向 $\theta[\mathrm{deg}]$ は，図 6(a)に示すように第 1 指内側に接する $Y$ 軸に平行な青 破線と，第 1 指の先頭に接する $X$ 軸に平行な青点線との交点を赤点線で示すように原点と結び，赤点線と第 5 指 の中足指節関節（MP 関節）を結ぶ角度を 3 等分することで決定する．また，右片足支持における(2)〜6)は $Y$ 軸 から右回りに $\theta=30 ， 60 ，-30 ， 90 ，-90 \mathrm{deg}$ ，左片足支持における(2)〜6は左回りに $\theta=-30 ，-60 ， 30 ，-90 ， 90 \mathrm{deg}$ とする.これらの角度は，被験者がサポート部の傾斜方向と平行にCOP を移動させ易いように，バランス維持に 重要と指摘されている (Hiramatsu and Izumi, 2010)足指の関節位置を主に考慮して決定した. 測定対象は表 2 に示 す健常者 12 名 とする. なお，表 2 中の SD は標準偏差，M は男性，F は女性を示す.

Table 2 Subjects for measuring the center of pressure

\begin{tabular}{c|c|c|c|c}
\hline Subject & Sex & Age [years] & Height [mm] & Weight [kg] \\
\hline \hline 1 & M & 21 & 1790 & 60 \\
\hline 2 & M & 23 & 1740 & 64 \\
\hline 3 & M & 24 & 1830 & 65 \\
\hline 4 & M & 33 & 1730 & 70 \\
\hline 5 & M & 34 & 1690 & 66 \\
\hline 6 & M & 47 & 1650 & 61 \\
\hline 7 & M & 47 & 1600 & 57 \\
\hline 8 & M & 48 & 1750 & 82 \\
\hline 9 & F & 21 & 1590 & 48 \\
\hline 10 & F & 23 & 1690 & 67 \\
\hline 11 & F & 24 & 1600 & 45 \\
\hline 12 & F & 35 & 1630 & 45 \\
\hline \hline & M & $34.6 \pm 11.5$ & $1722.5 \pm 74.2$ & $65.6 \pm 7.7$ \\
\cline { 2 - 5 } Average \pm SD & F & $25.8 \pm 6.3$ & $1627.5 \pm 45.0$ & $51.3 \pm 10.6$ \\
\cline { 2 - 5 } & Total & $31.7 \pm 10.7$ & $1690.8 \pm 79.0$ & $60.8 \pm 10.9$ \\
\hline
\end{tabular}

\section{$3 \cdot 4$ 転倒の判別}

測定結果の例として以下に身長 $1830 \mathrm{~mm}$, 体重 $65 \mathrm{~kg}$ の 24 歳成人男性（表 2 の被験者 3）と，身長 $1690 \mathrm{mm,}$ 体重 $66 \mathrm{~kg}$ の 34 歳成人男性（表 2 の被験者 5）の 2 名で行った測定結果を示す。まず，前節で述べた測定におい 
て各ワイヤ張力から求められる $X, Y$ および $Z$ 軸周りのモーメントの二乗和平方根である点 $\mathrm{O}$ 周りの合モーメン トと，フォースプレートで測定する被験者の COP の時間に対する変化から，転倒限界の判別を行う方法について 検討する.

図 6(a)の方向(4) 被験者 3が姿勢を傾斜した場合の装置動作開始時からの合モーメントおよびCOP の移動量の 時間に対する変化を図 7 に示す. 図 7 より, 測定開始から約 $24 \mathrm{~s}$ 後に合モーメントおよびCOP が急変している. これは, 被験者がバランスを維持できなくなり姿勢を崩して COP が急変し, サポート部に寄りかかったためであ る.いずれの変化も顕著であるが，本論文では転倒時の COP の測定を目的とするため， COP が急変する時間を 転倒限界の判別に用いる. ただし, 先述のとおり装置は合モーメントの急変で被験者の転倒を判断し停止する.

\section{$3 \cdot 5$ 測定結果}

被験者 3 および 5 の両足支持状態での姿勢傾斜に対する COP の変化および転倒限界でのCOP の位置を図 8 に, それぞれ赤小丸および青四角で, 各被験者の足部接地状態の足型とともに示寸. 足型は, 透明なアクリル板上で, 被験者の立位姿勢を測定時と同じ状態とし，足部接地面を下部から撮影した結果を元に作成した画像である.

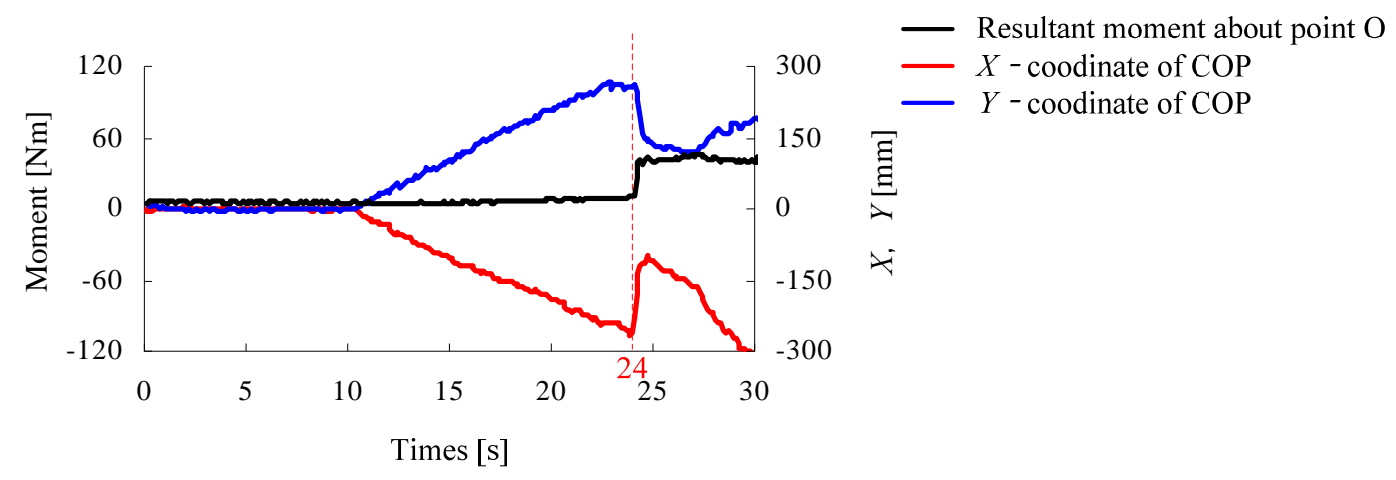

Fig. 7 Changes in the resultant moment and position of center of pressure: COP. Resultant moment, which were calculated from the tension induced at each wire, is plotted with the black line. $X$ and $Y$ coordinates measured by the force plate are plotted with red and blue lines respectively. Upright balance was lost at $24 \mathrm{sec}$ when these values showed rapid change.

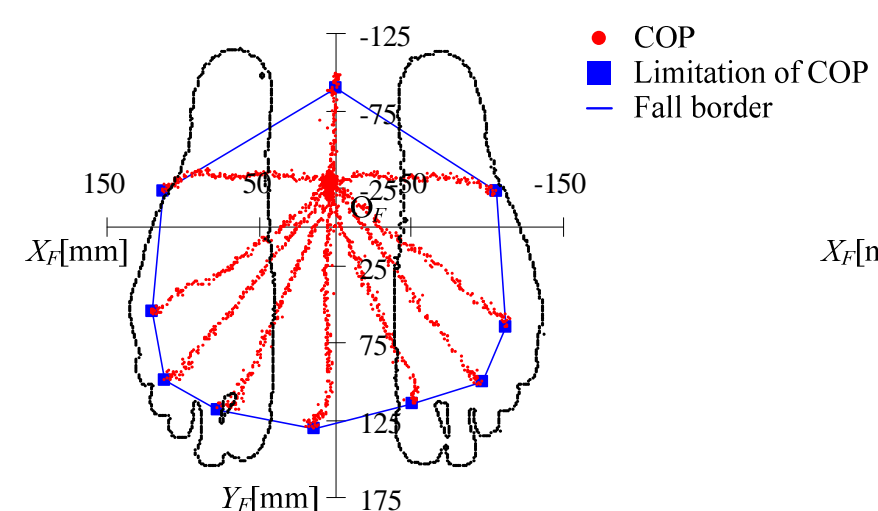

$Y_{F}[\mathrm{~mm}] \perp-175$

$A=62086 \mathrm{~mm}^{2} \quad T=39458 \mathrm{~mm}^{2} \quad T_{A}=0.636$

(a) Subject 3

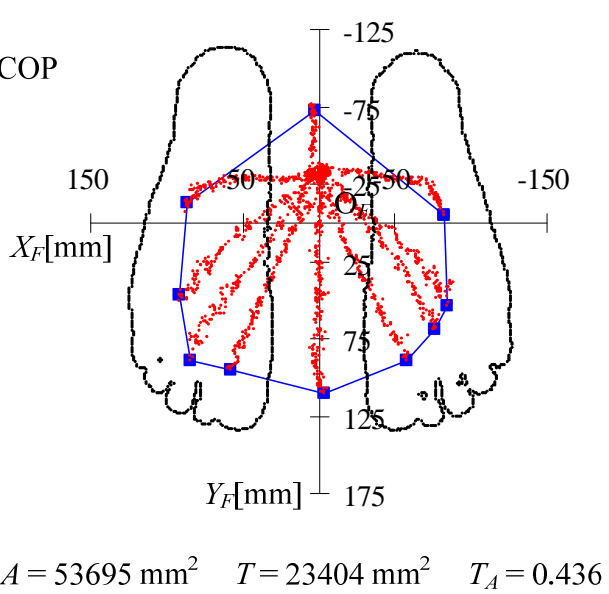

(b) Subject 5

Fig. 8 Path of COP to the limitation of maintaining the balance on both feet. COPs measured by the force plate are plotted with red circles. Blue squares denote the positions of COPs at falls. The aria by connecting the blue squares is used as the movable area of COP.

また，同様に片足支持状態での結果を図 9 に示す。片足支持での足型は，両足支持での足型測定結果を利用し ている.なお，座標系は図 1 に示したフォースプレートの中心を原点とする $\mathrm{O}_{F}-X_{F} Y_{F}$ を用いている. 
図 8 より, いずれの被験者においても設定した傾斜方向にCOP は，ほぼ追従している．また，転倒限界の COP の位置は, いずれの場合も足のふちのの内側であることが確認される.これは, 被験者の COP は静力学的な釣り合 い条件より足の支持基底面を超えられない (小川，2001) ためである．

COP が足のふらに達する前にバランスを失う原因として, 前方向の傾斜に関しては, 図 10 に示すようにつま 先立ち状態となり足指に大きな力が作用し，指による支持力が限界に達寸ることが考えられる．また，後方に関 しては，足関節に作用するモーメントが関節の発生力の限界に達するためと考えられる．さらに，片足支持状態 では，接地していない足を図 5 に示すように支持脚に密着しているため，身体の左右のバランスをとりにくく， また，大きなモーメントが足関節に作用することなどが原因と考えられる．ただし，詳細な考察は足関節の発生 力, 可動域, 足圧分布などを測定した上でバイオメカニクス的な検討が必要であり, 将来的な課題の一つである.

なお，図8(a)における被験者 3 の方向8)での転倒限界は足のふちを超えており，支持基底面の外にCOP が存在 している.これは図 11 に示すように，身体側面方向への身体傾斜角度が大きくなると足関節を内転し，測定開始 時には接していなかった足の横尔ちで身体を支えたためである.

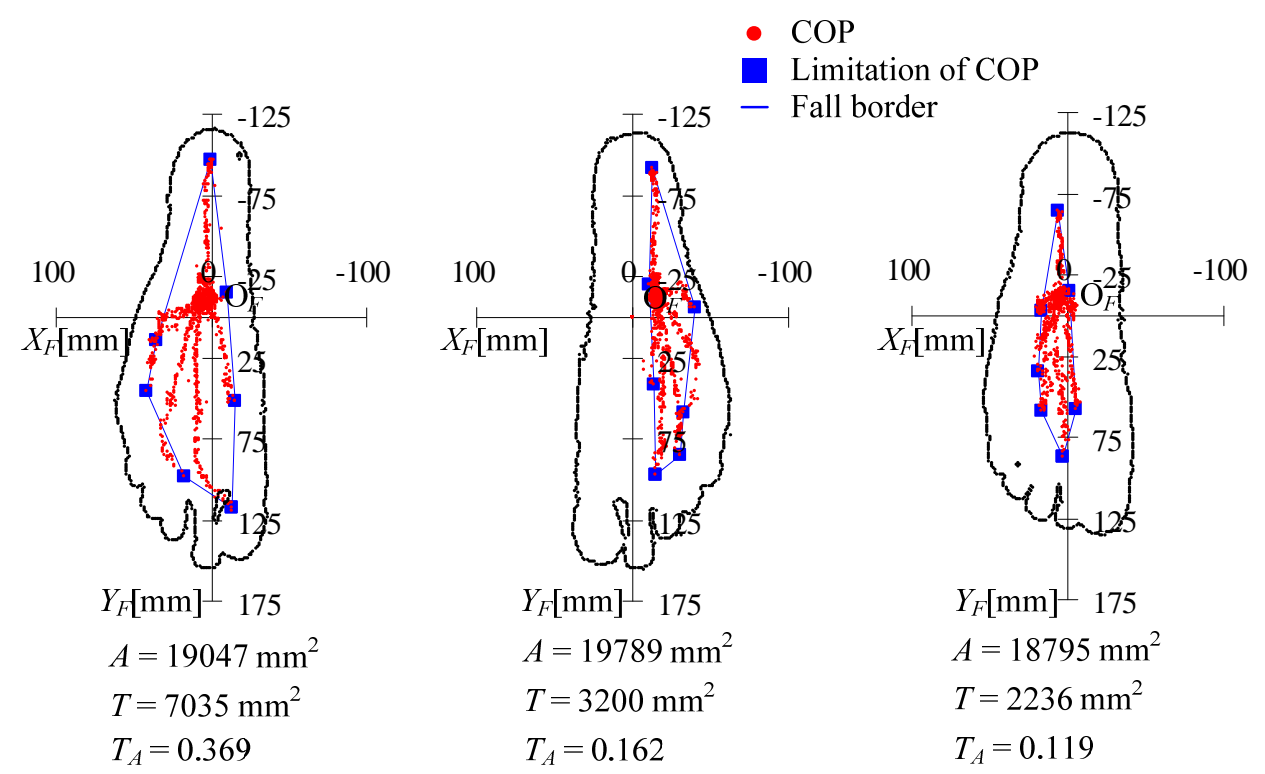

(a) Right foot: subject 3

(b) Left foot: subject 3

(c) Right foot: subject 5

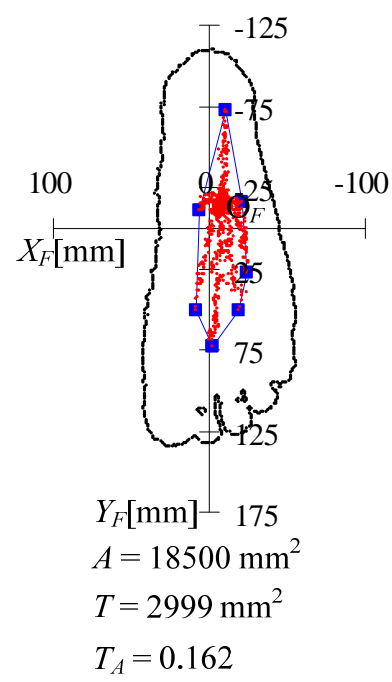

(d) Left foot: subject 5

Fig. 9 Path of COP to the limitation of maintaining the balance on one foot. COPs measured by the force plate are plotted with red circles. Blue squares denote the positions of COPs at falls. The aria by connecting the blue squares is used as the movable area of COP.
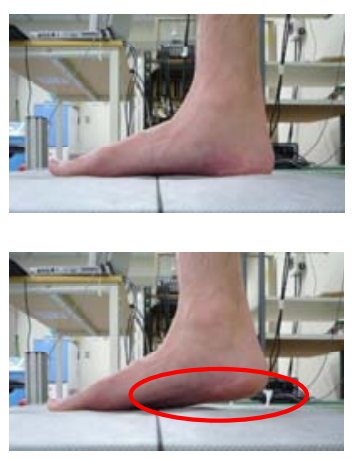

Fig. 10 Right foot on tilting (Subject 3)
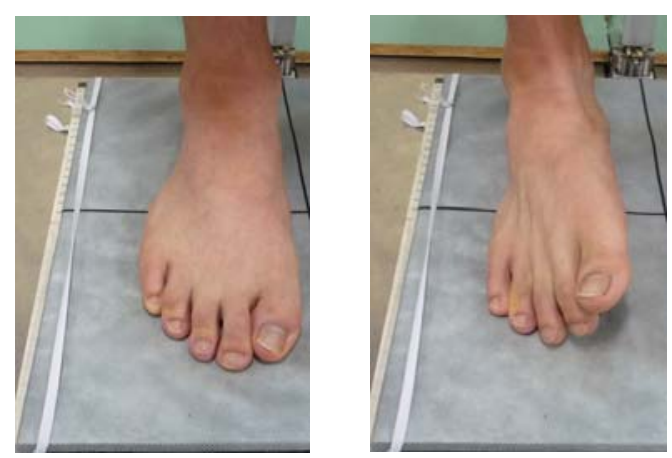

Fig. 11 Right foot on side tilting (Subject 3)

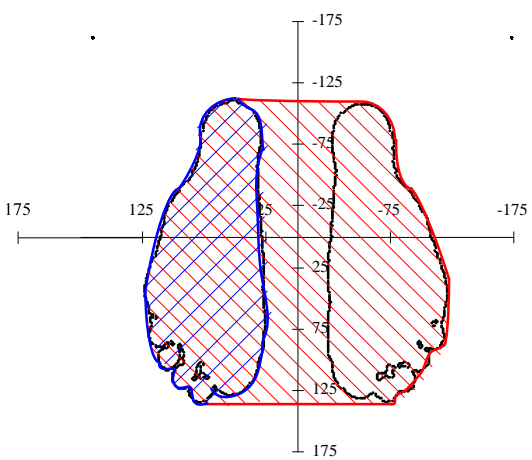

Fig. 12 Definition about base of support 


\section{$3 \cdot 6$ 測定結果の評価}

以上で測定した転倒限界での COP の位置より，立位バランス能力の評価を試みる. 本論文では，図 8(a)に示す ようにロを直線で接続した領域を, 身体の傾斜に対し立位バランスを保持可能な COP の範囲である COP 可動域 とする．なお，評価には身体寸法の異なる被験者の COP 可動域を比較するため，幾何学的に COP が存在可能な 支持基底面に対する $\mathrm{COP}$ 可動域の割合を用いる．支持基底面は図 12 に例を示すように，両足支持の場合，赤実 線のように両足の足趾先端と踵後端を直線で結び足型を囲む面 (小川, 2001), 片足支持の場合, 青実線のように 支持している側の足型そのものを囲む面とする．これらの支持基底面の面積 $A\left[\mathrm{~mm}^{2}\right]$ こり COP 可動域の面積 $T\left[\mathrm{~mm}^{2}\right]$ を除した面積比 $T_{A}$ を評価に用いる.

以上のようにして求めた， $A, T$ および $T_{A}$ の值をそれぞれの測定結果に対して図 8,9 中に記す. 被験者 3 と 5 の $T_{A}$ を比較すれば, 被験者 3 は, 両足, 片足支持のいずれにおいても大きな数值を示し, 被験者 5 に比べ立位を 保ちながら姿勢を大きく傾斜できることが把握される.

図13(a)には全被験者の両足支持, 右片足支持, 左片足支持それぞれの $T_{A}$ の值を示す. 被験者数が少ないため, おおよその傾向であるが, 被験者全体の $T_{A}$ の平均值に着目すると, 両足支持で 0.47 , 右片足支持で 0.22 , 左片足 支持で 0.19 であった. 片足支持の $T_{A}$ の值は両足支持の 5 割に満たず，健常者であってもバランスの維持は困難 であることがわかる. また, 両足支持での $T_{A}$ の值を同年代で比較すると, 男性に比べ女性は減少する傾向にあり, 20 代では 0.07， 30 代では 0.09 減少する. 同性で比較すると，年齢が上がるにつれて減少する傾向にあり，男性 では年代が上がるにつれて約 0.08 ずつ減少，女性では 0.10 減少している. 片足支持においても同様の傾向が見ら れるが，その差は両足支持に比べれば小さい. これは，上述のように片足支持での $T_{A}$ の值が両足支持での值に比 べてかなり低く，值そのものが小さいことから差が表れにくかったと考えられる.

以上で得られた結果に関して, 被験者数は 12 名と少ないが, 参考までに, 年齢, 性別による差の有意性を統計 的に判定する. 図 13(b)に示すように，被験者を 6 名ずつ 20 代の青年群と 30〜 40 代の中年群に分け，両群間の $T_{A}$ の值を対応のない $t$ 検定により危険率 $p$ 值を求め有意水準を $5 \%$ として判定した. なお，本論文ではエラーバ 一は標準偏差を示す. $T_{A}$ の平均土標準偏差は青年群において, 両足支持で $0.52 \pm 0.063$, 右片足支持で $0.26 \pm 0.062$, 左片足支持で $0.22 \pm 0.050$ であった. 一方，中年群では両足支持で $0.42 \pm 0.071$, 右片足支持で $0.18 \pm 0.057$, 左片 足支持で $0.15 \pm 0.020$ であった. $T_{A}$ の平均值は両足支持 $(t=2.322, p<0.05)$ およ゙左片足支持において $(t=2.750, p<0.05)$, 中年群では青年群に比べて有意に小さい值となった，また，右片足支持 $(t=2.078)$ においても，有意な差ではない が中年群では青年群に比べ小さい值となった。 これより, COP 可動域は加齡にともない減少すると推測できる.

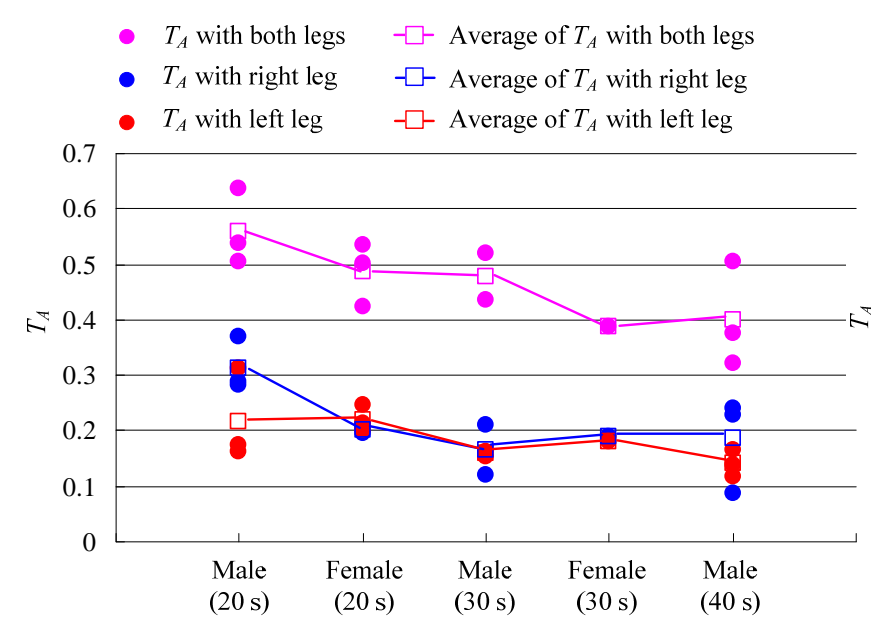

(a) $T_{A}$ of each subject standing on one foot or both feet

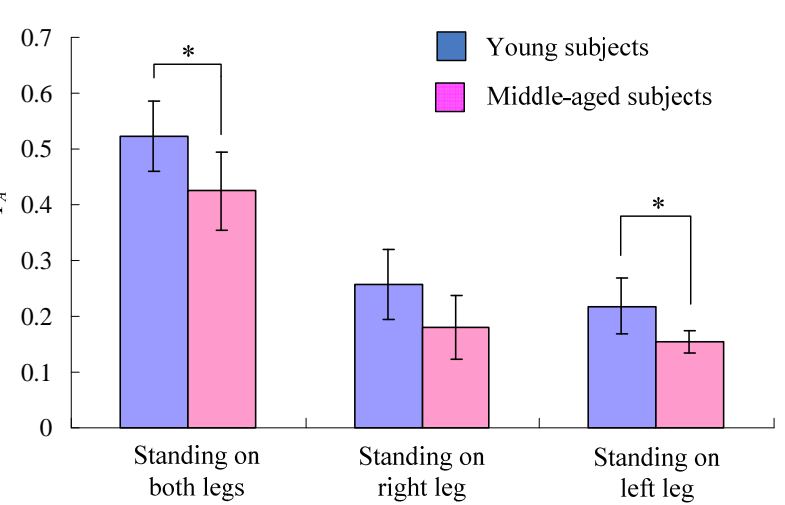

(b) Difference of average and standard deviation of $T_{A}$ between two groups $\left({ }^{*} p<0.05\right)$

Fig. 13 Comparison of $T_{A}$. Ratio of the movable area of COP to the area of base of support " $T_{A}$ " tends to decrease with age. The results show " $T_{A}$ ” can reveal individual difference numerically. 
さらに, $T_{A}$ の性別差について, 男性群 8 名と女性群 4 名それぞれ $T_{A}$ の平均值を求め $t$ 検定を行った. $T_{A}$ の平均 土標準偏差は，男性群では両足支持で $0.48 \pm 0.092$, 右片足支持で $0.23 \pm 0.086$, 左片足支持で $0.17 \pm 0.055$ であっ た. 一方, 女性群では両足支持で $0.46 \pm 0.059$, 右片足支持で $0.20 \pm 0.008$, 左片足支持で $0.21 \pm 0.024$ であった. $T_{A}$ の平均值には両足支持 $(t=0.322)$, 右片足支持 $(t=0.621)$ および左片足支持 $(t=1.177)$ のいずれにおいても，男女間に 有意な差は認められなかった，ただし，今回は男性群と女性群の人数差が大きく，また，女性群の年齢の平均土 標淮偏差である $25.8 \pm 6.3$ 歳が, 男性群の 34.6 11.5 歳に比べかなり若いことなどから, 性別に関する差に関して は, さらに，測定と検討が必要である.

ただし，図 8，9，13 のように，COP 可動域の測定結果は立位状態におけるバランス能力の個人差などを視覚 的, 数值的に表すことができる. したがって, 本装置による同測定結果は立位バランス能力の評価に有用である.

\section{4. 姿勢傾斜時の重心動摇}

\section{$4 \cdot 1$ 測定方法}

立位バランスを保てなくなる姿勢近傍での COP の変動, 寸なわち, 重心動摇の測定は被験者の安全のため通常 は困難であるが，前章までの結果より，製作した装置を用いれば可能となる，そこで，以上の結果を参考に転倒 限界近傍を含む傾斜した姿勢での重心動摇を測定し, 通常用いられる直立姿勢の結果と比較する. 測定の手順を (1) 〜 (3) に示寸.

(1) $3 \cdot 2$ 節で述べた直立姿勢となるように立ち位置などを調整する. ただし, サポート部には図 14 に示す, 装置 の上部からワイヤにより吊り下げたハーネス (インターリ八製)を用い, 被験者の胸部および大腿部に装着する.

（2）姿勢の傾斜は COP の位置で規定することとし，サポート部を動作させ，被験者の COP が目標位置に達する まで身体を足関節まわりに傾斜させる.

（3）サポート部を停止し, 被験者には姿勢を傾斜させたままで静止立位状態を続けさせる. この時の重心動摇を 20 s 間測定する.

なお，測定中はディスプレイを被験者の前方に配置し，COP とその目標位置を $\mathrm{O}_{F}-X_{F} Y_{F}$ 上に表示する. 被験者 には COP と目標位置が一致するように努めてもらう。COP の目標位置は, 図 15 に例を示す, 被験者の足長に対 寸る踵からの距離の割合 $C_{r}[\%]$ で指定する．測定は，直立姿勢， $C_{r}$ の目標值を $60 \%, 70$ \%に設定した 2 箇所お

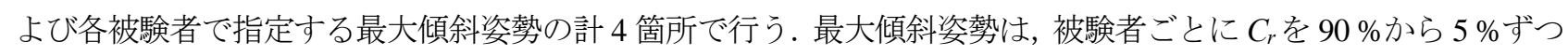
変化させ，立位姿勢を $20 \mathrm{~s}$ 間以上維持可能であった最大の $C_{r}$ での姿勢とする.

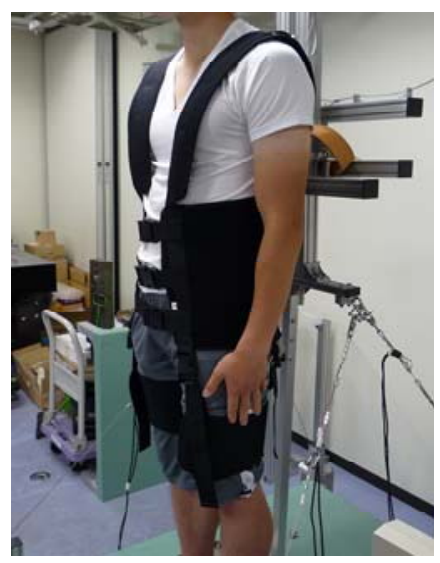

Fig.14 Situation of wearing a harness

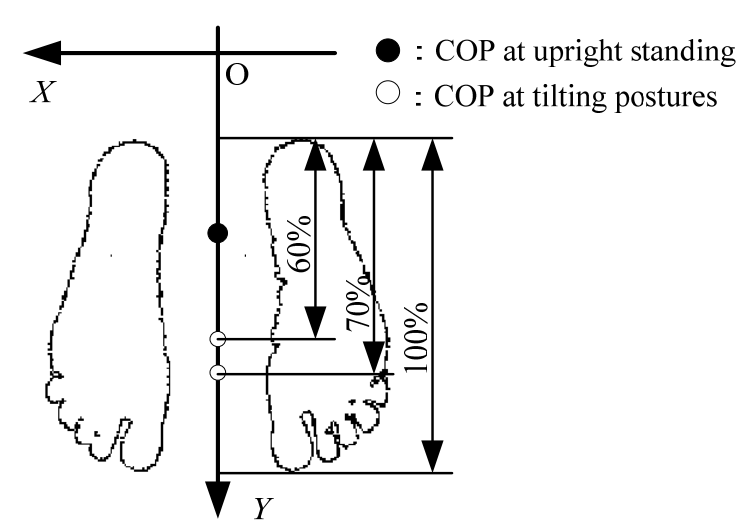

Fig. 15 Target position of $C_{r}$ on measuring postural sway at tilting posture 


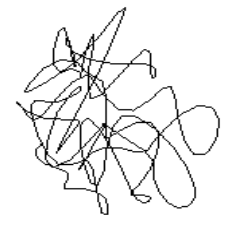

(a) COP trajectory

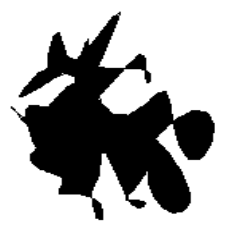

(b) Sway area

Fig. 16 Definition about Sway area

サンプリング周波数を $20 \mathrm{~Hz}$ とした測定時間 $20 \mathrm{~s}$ 中の 5 〜 $15 \mathrm{~s}$ における $10 \mathrm{~s}$ 間の結果より，重心動摇の評価に よく用いられる (堀川他, 1999) COP の総移動距離 $L[\mathrm{~mm}]$ およびその移動範囲である外周面積 $S\left[\mathrm{~mm}^{2}\right]$ を算出する. さらに, $S$ の值を $3 \cdot 6$ 節の図 12 に示した各被験者の支持基底面の面積 $A\left[\mathrm{~mm}^{2}\right]$ で除した面積比 $S_{A}$ を算出する. な お, $L$ の值はサンプリング数が $n$ である $\mathrm{O}_{F}-X_{F} Y_{F}$ 上における COP の座標 $\left(x_{i}, y_{i}\right)[i=1 \sim n]$ から次式で算出する.

$$
L=\sum_{i=1}^{n-1} \sqrt{\left(x_{i}-x_{i+1}\right)^{2}+\left(y_{i}-y_{i+1}\right)^{2}}
$$

$S$ の值は，図 16(a)に示す COP の移動軌跡の測定結果例において，軌跡の最外郭で囲まれる図 16(b)に示寸黒塗 り部分の面積として求める. 被験者は表 3 に示寸健常者 10 名（22.9 0.7 歳; 男性 10 名）とし，両足支持と右片 足支持それぞれで測定を行った. 測定は各条件で 2 回ずつ行った. なお， $S$ の值は COP が一瞬であっても大きく 変位した場合に急増する. 今回は, 測定時間全体の傾向をより表す結果として, $S$ が小さいほうの結果を用いた.

Table 3 Subjects for measuring body sway at tilting

\begin{tabular}{c|c|c|c|c}
\hline Subject & Sex & Age [years] & Height [mm] & Weight [kg] \\
\hline \hline 1 & M & 22 & 1790 & 60 \\
\hline 2 & M & 23 & 1740 & 64 \\
\hline 3 & M & 23 & 1690 & 58 \\
\hline 4 & M & 23 & 1770 & 60 \\
\hline 5 & M & 23 & 1730 & 68 \\
\hline 6 & M & 23 & 1770 & 61 \\
\hline 7 & $\mathrm{M}$ & 24 & 1600 & 57 \\
\hline 8 & $\mathrm{M}$ & 22 & 1750 & 65 \\
\hline 9 & $\mathrm{M}$ & 22 & 1640 & 52 \\
\hline 10 & $\mathrm{M}$ & 24 & 1660 & 56 \\
\hline \hline \multicolumn{2}{|c|}{ Average \pm SD } & $22.9 \pm 0.7$ & $1714.0 \pm 61.1$ & $60.1 \pm 5.0$ \\
\hline
\end{tabular}

\section{$4 \cdot 2$ 測定結果と評価}

まず，両足支持における結果について述べる．図 17 に各被験者のそれぞれの $C_{r}$ において測定值から算出した $L$ および $S_{A}$ の平均值と標準偏差を示す. なお， $C_{r}$ の值は前節で述べた目標值に対して各被験者で実際に測定され た結果の平均值と標準偏差である. 図 18 には COP の測定結果の例として, 2 名の 20 代男性（表 3 の被験者 2, 3）の各 $C_{r}$ の目標值において測定した COP の軌跡を示す. なお，同図中では測定時間内の COP の平均值として 求めた重心動摇の中心を原点 $\mathrm{O}_{\mathrm{s}}$ とし, 各軸が $X_{F}, Y_{F}$ 軸と平行な座標系 $\mathrm{O}_{\mathrm{s}}-X_{S} Y_{S}$ で $\mathrm{COP}$ の変化を表している.

図 17 より， $C_{r}$ の増加にともない $L$ および $S_{A}$ の值は増加する. これらの有意差を判定するため, 対応のある一 元配置分散分析を行った. なお, 有意水準は 5 \%とした. 分散分析の結果, 平均值間の有意差が $L(F(3,27)=20.11$, $p<0.01)$ および $S_{A}(F(3,27)=5.87, p<0.01)$ でともに認められた。 なお， $F(x, y)$ は分散分析において，因子（被験者） の水準間変動の自由度を $x$, 誤差変動の自由度を $y$ として得られた分散比の值を示寸. さらに, これらの結果に 
おいて Tukey の HSD 法 (出村, 2007) による多重比較検定を行い， $C_{r}$ の目標位置間での有意差を検討した結果, 図 17 に示寸ように姿勢の傾斜とともに $C_{r}$ に対する有意差が表れ， $L, S_{A}$ とともに最大傾斜姿勢において, 直立姿 勢および $C_{r}$ の目標值を 60 \%とした傾斜姿勢と比較し有意な増加を示寸ことが確認された.

さらに，図 17 に示寸標準偏差の值より，最大傾斜姿勢では $L ， S_{A}$ のばらつき，すなわち，個人差が他の傾斜姿 勢に比べ大きい. 例として, 図 18(a)より被験者 2 の重心動摇は, 最大傾斜姿勢である $C_{r}$ が 80 \%において最も大 きい，同被験者の最大傾斜姿勢における $L$ および $S_{A}$ の值は直立姿勢に比べ，それぞれ 2.8 倍， 7.7 倍となってお り， $S_{A}$ の值が顕著に増加している。，一方，図18(b)より被験者 3 の重心動摇は， $C_{r}$ の増加にともなう $L$ および $S_{A}$ の值の増加傾向が比較的小さい.

これらの結果から， $C_{r}$ の増加による影響を受けやすい被験者と受けにくい被験者が存在し，身体を傾斜させる ことで個人差が顕著になると考えられる. 一方, 本測定の範囲では直立状態において被験者間の $L$ および $S_{A}$ 差 は小さい. 重心動摇の測定は主に直立状態で行われることが多いが，以上のように姿勢を傾斜するにつれて個人 差が顕著となることから，本装置による測定はバランス能力の優劣の評価をより適切に示し得る.

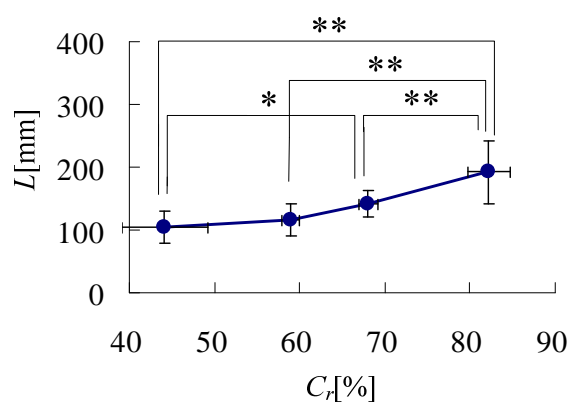

(a) Total liner length of COP trajectory at tilting on both feet

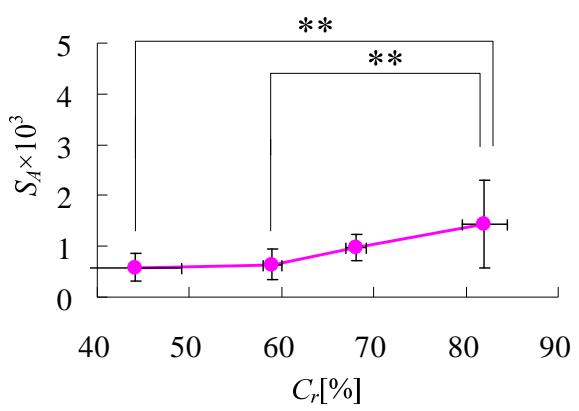

(b) $S_{A}$ at tilting on both feet

Fig. 17 Comparison of each subjects about $L$ and $S_{A}\left({ }^{* *} p<0.01,{ }^{*} p<0.05\right)$ at standing on both feet. $L$ and $S_{A}$ tend to increase with $C_{r}$; they display great variation at the maximum of $C_{r}$.

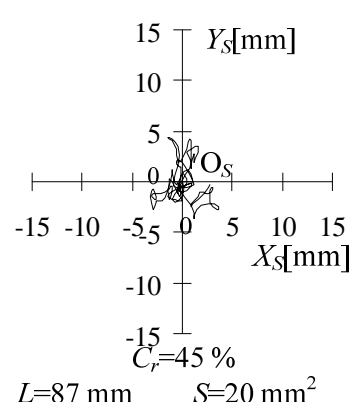

$A=50561 \mathrm{~mm}^{2} S_{A}=0.40 \times 10^{-3}$

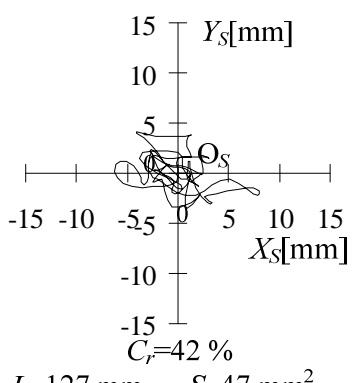

$L=127 \mathrm{~mm} \quad S=47 \mathrm{~mm}^{2}$ $A=58694 \mathrm{~mm}^{2} S_{A}=0.80 \times 10^{-3}$
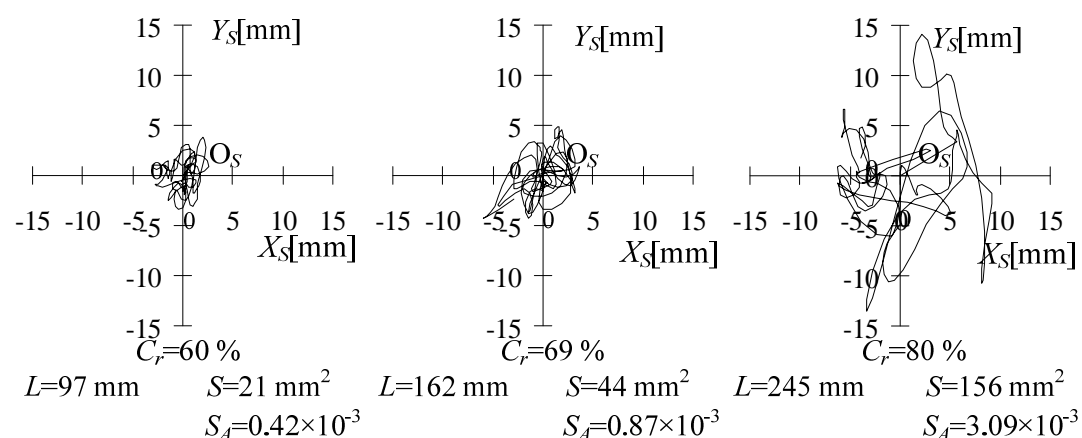

(a) Subject 2

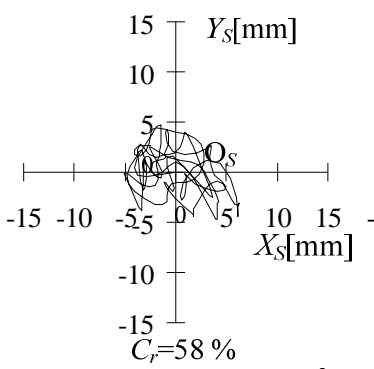

$L=163 \mathrm{~mm}$

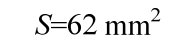
$S_{A}=1.06 \times 10^{-3}$
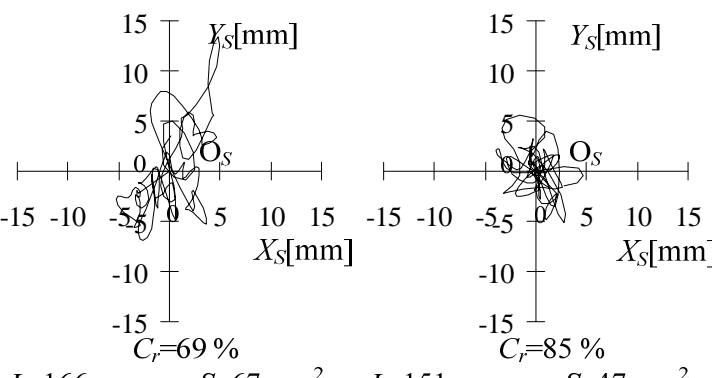

(b) Subject 3

Fig. 18 Tilting postural sway at standing on both foot 
次に，右片足支持における結果について述べる. 図 19 に各被験者の各 $C_{r}$ の目標值において測定値から算出し た $L$ および $S_{A}$ の平均值と標準偏差を示寸. $C_{r}$ の值は先と同じく測定值の平均值と標準偏差である. 図 20 には COP の測定結果の例として，2名の 20 代男性（被験者 2，3）の各 $C_{r}$ において測定した COP の軌跡を示す.

図 19 より測定時の $C_{r}$ に対する $L$ および $S_{A}$ の全体的な平均值は両足支持での結果と比べ，それぞれ， 3 倍およ び 8 倍程度とかなり大きい. しかし， $C_{r}$ の増加にともなう $L$ および $S_{A}$ の平均值の変化は小さく, 分散分析による

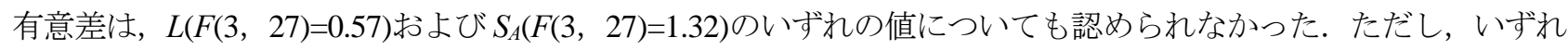
の $C_{r}$ においても $L$ および $S_{A}$ のばらつきは大きい.

図 19 に示寸ように右片足支持での $L$ および $S_{A}$ の值は直立姿勢時においても両足支持での最大傾斜姿勢時より も大きい.すなわち, $3 \cdot 6$ 節での COP 可動域の測定結果においても述べたように，片足支持でバランスを保つ

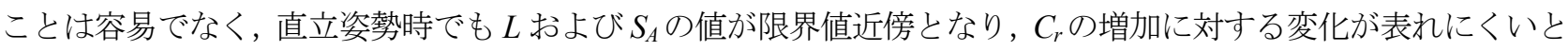
考えられる.

図 20(a)より被験者 2 の重心動摇について検討すると，Lの值はいずれの姿勢においても約 $300 \mathrm{~mm}$ であるのに 対し, $S_{A}$ の值は $C_{r}$ が $60 \%, 67 \%$ の傾斜姿勢において, 直立姿勢, 最大傾斜姿勢と比べて小さいことがわかる. 一方，同図(b)より被験者 3 では $L$ の值が約 $400 \mathrm{~mm}$ であり，被験者 2 に比べて $100 \mathrm{~mm}$ 大きい. また， $S_{A}$ の值は $C_{r}$ が $59 \%, 68$ \%の傾斜姿勢で比較的大きく, 被験者 2 とは異なった変化の傾向を示している.

これらの結果および図 19 に示した $L$ および $S_{A}$ のばらつきより, 片足支持においては姿勢を傾斜しない状態に おいても個人差が顕著に表れる.すなわち，片足支持における重心動摇の評価は，立位バランス能力の評価に有 用と考えられるが，以上述べたように同状態は不安定な状態であり，健常者以外にとっては困難な姿勢である. 実用的な観点からは，両足支持で姿勢を傾斜させ重心動摇を測定する方法が適すると予想される.

以上，提案する装置は転倒にいたるまでの COP や重心動摇を安全に測定可能であり，その結果は被験者のバラ ンス能力を数值的に明示し得る. そこで, 今後は対象とする被験者の数と範囲を増やし，ヒトの各種身体能力と 本装置で測定が可能な転倒限界や姿勢傾斜時の重心動摇との関係を明らかにするとともに，転倒経験の有無など との関連を調査して，ヒトの転倒しやすさの評価法としての発展を図る．そのために，まず，効率的な測定条件 を検討する. 本論文で実施した COP 可動域の測定, 身体傾斜時の重心動摇の測定では, いずれの場合も被験者に は，長時間にわたり，身体に負荷が作用する姿勢を課すとともに，指定した姿勢をとるための緊張を要求する. 今回は，適宜，休㮩を設けながら測定を行ったが，実用化時に本論文で示したような多数の条件で測定を行うこ とは困難である。

そこで，被験者への負担を軽減するとともに測定時間を短縮するため, COP 可動域の評価では, 姿勢の傾斜方 向を限定し測定回数を減らすことを目的として, 同領域の評価が適切に可能な少数の姿勢の傾斜方向を明らかに する. また, 姿勢傾斜時の重心動摇の評価に関しては, 年齢や疾患の状況に応じた, 身体への負荷を抑制しつつ, 立位バランス能力の評価が可能な傾斜姿勢を，医療関係者らの協力により検討していく.

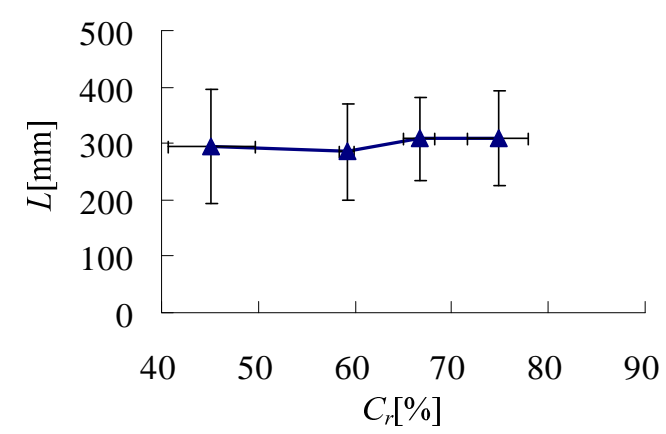

(a) Total liner length of COP trajectory at tilting on right foot

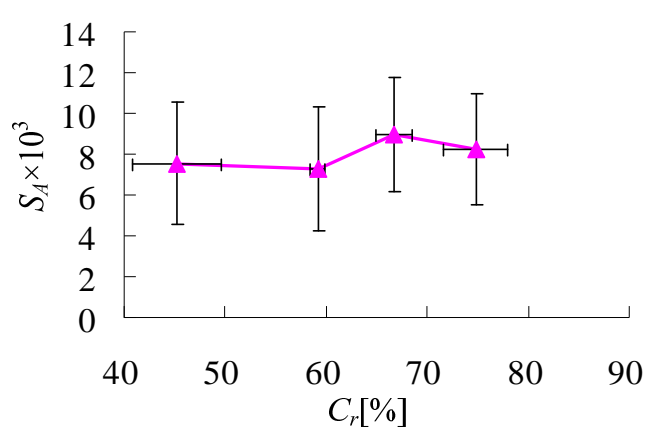

(b) $S_{A}$ at tilting on right foot

Fig. 19 Comparison of each subjects about $L$ and $S_{A}\left({ }^{* *} p<0.01,{ }^{*} p<0.05\right)$ at standing on right foot. $L$ and $S_{A}$ show little changes with $C_{r}$; they display great variation overall range $C_{r}$. 


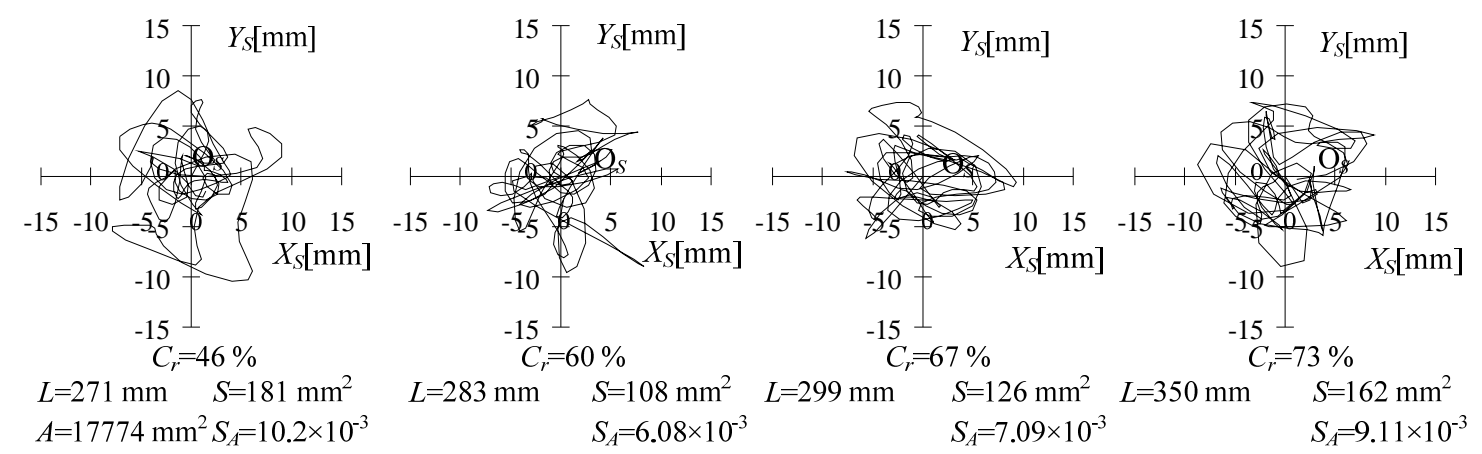

(a) Subject2

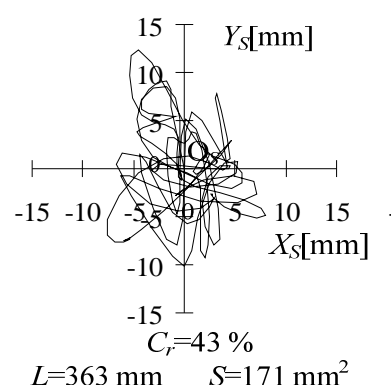

$A=22971 \mathrm{~mm}^{2} S_{A}=7.44 \times 10^{-3}$

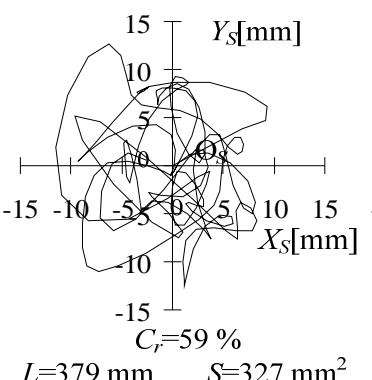

$L=379 \mathrm{~mm} \quad \begin{aligned} & S=327 \mathrm{~mm}^{2} \\ & S_{A}=14.2 \times 10^{-3}\end{aligned}$

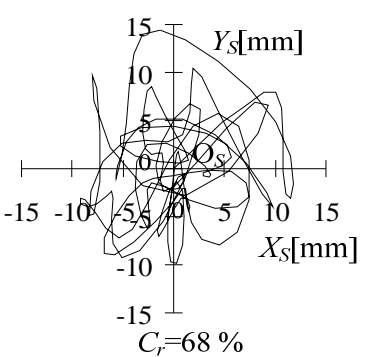

$S=312 \mathrm{~mm}^{2} \quad L=399 \mathrm{~mm}$ $S_{A}=13.6 \times 10^{-3}$

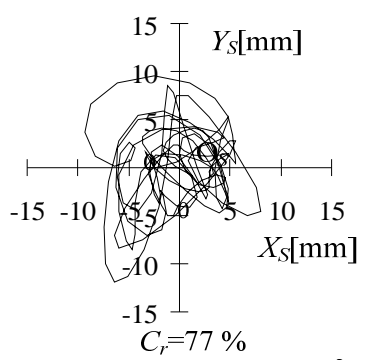

$S=215 \mathrm{~mm}^{2}$ $S_{A}=9.36 \times 10^{-3}$

(b) Subject3

Fig. 20 Tilting postural sway at standing on right foot

\section{5. 結}

（1）被験者の身体を複数方向に誘導して傾斜させ足圧中心の変化などを測定可能な立位バランス能力測定装置 を，パラレルワイヤ駆動機構を用いて製作した。同装置は，被験者がバランスを維持できず転倒した場合には速 やかに身体を保持し安全を確保できるため，転倒リスクが高い姿勢においても安全にヒトの立位バランスに関す る能力の測定が行える.

(2) 開発した装置を用い，立位バランスが維持可能な足圧中心位置の限界を安全に測定可能であることを確認し た. また，得られた測定結果より求めた足圧中心の可動域より，ヒトのバランス維持能力を視覚的，数值的に評 価および比較可能であることを示した.

（3）両足支持において姿勢を傾斜させ重心動摇の測定を行った結果，バランス維持が可能な姿勢の限界に近づく につれ足圧中心位置の変動が激しくなり個人差が顕著に表れ，片足支持では姿勢を傾斜させない場合でも同様な 傾向が見られた，これらの結果より，本装置を用いれば，不安定な姿勢でも安全を確保しながら，従来行われて きた安定した直立姿勢での測定に比べ，より明確に立位バランスの差異を表す能力の測定が可能である.

\section{謝 辞}

本研究を遂行するにあたり，金沢大学医薬保健研究域 西村誠次准教授，金沢大学理工研究域 吉田博一技術 職員の多大なる協力を得ました。また，科学研究費補助金基盤研究（C）20560129および涉谷学術文化スポーツ 振興財団の支援を受けました。ここに記し，深く感謝の意を表します.

\section{文献}

Bottaro, A., Casadio, M., Morasso, P. G. and Sanguineti, V., Body sway during quiet standing, Human Movement Science, Vol.24 (2005), pp.588-615. 
出村慎一, 例解＼cjkstart健康・スポーツ科学のための統計学＼cjkstart改訂版, 第 2 版 (2007), p.271, 大修館書店.

Freitas, P. B. d., Freitas, S. M. S. F., Duarte, M., Latash, M. L. and Zatsiorsky, V. M., Effects of joint immobilization on standing balance, Human Movement Science, Vol.28 (2009), pp.515-528.

堀川悦夫, 中川貴志, 松井敏史, 岡村信行, 樋口真人, 荒井啓行, 佐々木英忠, 塚原保夫, 樹神学, 高齢者の易転倒 性の評価, 東北大医短部紀要, Vol.8, No.2 (1999), pp.183-190.

Hiramatsu, T. and Izumi, K., Relationship between characteristics of plantar pressure distribution while standing and falls in community-dwelling elderly, Journal of the Tsuruma Health Science Society, Vol.34, No.2 (2010), pp.51-63.

今本喜久子, 北村文月, 喜多義邦, 高田政彦, 日浦美保, 藤本悦子, 高齢者の転倒・骨折発生に関わる身体的リスク 要因, 滋賀医科大学看護学ジャーナル, Vol.3, No.1 (2005), pp.13-19.

木村みさか, 高齢者のバランス能 (平衡性) を評価することの意義, 日本生理人類学会誌, Vol.5, No.2 (2000), pp.17-24.

Kouzaki, M. and Msani, K., Postural sway during quiet standing is related to physiological tremor and muscle volume in young and elderly adults, Gait \& Posture, Vol.35, No.1 (2012), pp.11-17.

厚生労働省, 表 23 要介護度別にみた介護が必要となった主な原因の構成割合, 平成 22 年国民生活基礎調査の概 況 IVavailable from <http://www.mhlw.go.jp/toukei/saikin/hw/k-tyosa/k-tyosa10/4-2.html>, (参照日 2012 年 1 月 27 日).

毛利謙作, 岸孝司, 植田純乎, 津野裕子, 免荷機能付全方向移動歩行訓練機, 日本機械学会福祉工学シンポジウム 2009 講演論文集 (2009), pp.32-33.

小柏進也, 池添冬芽, 建内宏重, 曽田直樹, 坪山直生, 市橋則明, 高齢者の姿勢制御能力と転倒恐怖感および生活 活動量との関連, 理学療法学, Vol.37, No.2 (2010), pp.78-84.

小川鑛一, 看護動作を助ける基礎人間工学, 第 1 版 (2001), p.52, 東京電機大学出版局.

立矢宏, 荒井優樹, 奥野公輔, 宮崎祐介, 西村誠次, パラレルワイヤ駆動機構を用いた人体の転倒実験装置(座位 での転倒評価の検討), 日本機械学会論文集 C 編, Vol.76, No.770 (2010), pp.2621-2627.

立矢宏, 佐野嚴根, 奥野公輔, 宮崎祐介, 吉田博一, パラレルワイヤ駆動機構の張力評価による上体動作支援装置 の開発，日本機械学会論文集 C 編, Vol.73, No.727 (2007), pp.833-840.

安村誠司，高齢者の転倒・骨折の頻度，日医雑誌，Vol.122, No.13 (1999), pp.1945-1949.

\section{References}

Bottaro, A., Casadio, M., Morasso, P. G. and Sanguineti, V., Body sway during quiet standing, Human Movement Science, Vol.24 (2005), pp.588-615.

Demura, S., Reikai kenkou supootsukagaku no tame no toukeigaku, Taisyukan (2007), p.271 (in Japanese).

Freitas, P. B. d., Freitas, S. M. S. F., Duarte, M., Latash, M. L. and Zatsiorsky, V. M., Effects of joint immobilization on standing balance, Human Movement Science, Vol.28 (2009), pp.515-528.

Hiramatsu, T. and Izumi, K., Relationship between characteristics of plantar pressure distribution while standing and falls in community-dwelling elderly, Journal of the Tsuruma Health Science Society, Vol.34, No.2 (2010), pp.51-63.

Horikawa, E., Nakamura, T., Matsui, S., Okamura, N., Higuchi, M., Arai, H., Sasaki, H., Tsukahara, Y. and Kodama, M., An analysis of relationships between postural stability measures and falling in older people, Bulletin of College of Medical Sciences, Tohoku University, Vol.8, No.2 (1999), pp.183-190 (in Japanese).

Imamoto, K., Kitamura, F., Kita, Y., Takeda, M., Hiura, M. and Fujimoto, E., Physical risk factors related to the fall and bone fracture in the elderly - Transitional changes of the bone stiffness, muscular strength and postural sway -, Journal of nursing, Shiga University of Medical Science, Vol.3, No.1 (2005), pp.13-19 (in Japanese).

Kimura, M., Significance of evaluation of the valancing ability in the elderly (Special issue of physical fitness research interest group), Japanese journal of physiological anthropology, Vol.5, No.2 (2000), pp.65-72 (in Japanese).

Kouzaki, M. and Msani, K., Postural sway during quiet standing is related to physiological tremor and muscle volume in young and elderly adults, Gait \& Posture, Vol.35, No.1 (2012), pp.11-17.

Ministry of Health, Labour and Welfare., Table23 Percentage distribution of persons requiring long-term care by sex and age group, comprehensive survey of living conditions, available from $<$ http://www.mhlw.go.jp/toukei/saikin/hw/k-tyosa/k-tyosa10/4-2.html>, (accessed on 27 January, 2012) (in Japanese).

Mohri, K., Kishi, T., Ueda, J. and Tsuno, Y., Omini-directional walking rehabilitation machine with load support mechanism, Proceedings of The JSME Symposium on Welfare Engineering 2009 (2009), pp.32-33(in Japanese). 
Ogaya, S., Ikezoe, T., Zinnai, H., Sota, N., Tsuboyama, N. and Ichihashi, N., The relationship of fear of falling and daily activity to postural control in the elderly, The Journal of Japanese Physical Therapy Association, Vol.37, No.2 (2010), pp.78-84 (in Japanese).

Ogawa, K., Kangodousa wo tasukeru kisoningenkougaku, Tokyo Denki University Press (2001), p.52 (in Japanese).

Tachiya, H., Arai, Y., Okuno, K., Miyazaki, Y. and Nishimura, S., Experimental apparatus for fall behavior of human by using parallel wire mechanism (Consideration of evaluating fall at sitting posture), Transactions of the Japan Society of Mechanical Engineers, Series C, Vol.76, No.770 (2010), pp.2621-2627 (in Japanese).

Tachiya, H., Sano, I., Okuno, K., Miyazaki, Y. and Yoshida, H., Development of the upper body motion assist system using a parallel wire mechanism by evaluating the driving tensions (machine elements and manufacturing), Transactions of the Japan Society of Mechanical Engineers, Series C, Vol.73, No.727 (2007), pp.833-840 (in Japanese).

Yasumura, S., Koureisya no tentou kossetsu no hindo, The Journal of the Japan Medical Association, Vol.122, No.3 (1999), pp.1945-1949 (in Japanese). 